\title{
External competitiveness and the role of fiscal policy: does fiscal austerity matter?
}

\author{
Boris Cota $^{1}$, Nataša Erjavec ${ }^{1}$, Velibor Mačkić ${ }^{1, *}$ \\ ${ }^{1}$ Faculty of Economics and Business, University of Zagreb \\ Trg J. F. Kennedyja 6, 1000 Zagreb, Croatia \\ E-mail: 〈\{bcota, nerjavec, vmackic\}@efzg.hr $\rangle$
}

\begin{abstract}
During and after the sovereign debt crisis that hit most of the EU member states after the Great Recession, the question of the effectiveness of fiscal policy vis-à-vis ensuring sustainable growth rates and changing the economic structure of member states was highly debated. Accordingly, this paper investigates the effects of shocks in government purchases and net taxes on the export competitiveness of the eleven new EU member states: Bulgaria, the Czech Republic, Estonia, Croatia, Latvia, Lithuania, Hungary, Poland, Romania, Slovenia and Slovakia. The countries are treated as a homogenous sample, but the empirical analysis extends beyond this. Namely, the paper examines two subsamples based on the exchange rate regimes of the eleven new EU member states: the fixed vs the flexible exchange rate regime. By applying the panel VAR analysis, over the 1999-2015 period, we have reached the following conclusions. First, fiscal austerity influences the level of exports in our sample. Second, the effects of shocks in fiscal policy on the level of exports are short-lived. Third, shocks in government purchases are the most important determinant for all the new EU member states. And fourth, shocks in net taxes influence the level of export only in the countries that have the flexible exchange rate regimes. Our results contribute to the literature that examines the effects of fiscal policy on the competitiveness of national economies by highlighting both the duration effect of fiscal policy on the level of export and also by pointing to the optimal economic instrument used with respect to the currency arrangement of the country.
\end{abstract}

Keywords: export, external competitiveness, fiscal consolidation, new EU member states, panel data

Received: October 8, 2018; accepted: January 8, 2019; available online: July 4, 2019

DOI: $10.17535 /$ crorr.2019.0006

\section{Introduction}

The question of the economic policy is often reviewed. This is especially true during and after the times of crisis such as the sovereign debt crisis that hit most of the EU member states after the Great Recession. If the importance and advantages of the independent monetary policy, $[5,16,18]$, are taken into account as well, the focus of the discussion moves to the role of the fiscal policy. If one adds to this the EU policy emphasis on the fiscal austerity, under the prevailing influence of the German and the European Central Bank [34] the interest in Europe is clear.

The issue of fiscal austerity positions itself as equally important for all the $28 \mathrm{EU}$ member states due to the centralized monetary policy, different exchange rate mechanisms and ideological views on the role of the state (pro-Keynesian vs anti-Keynesian macroeconomic management). For the small open economies, overall, and even more so for the new EU member states, this leads academics, policymakers and the general public to the following question.

${ }^{*}$ Corresponding author. 
Do internal and external balances move in the same direction? More directly, does reducing budget deficit also reduce the current account deficit in the light of the twin deficits hypothesis?

Taking that into account, the main motivation of this paper stems from empirically inconclusive results of the research on the effects of fiscal austerity on the external balance and the composition of GDP. There are still no clear answers to the question of the effectiveness of fiscal policy vis-à-vis ensuring sustainable growth rates and changing the economic structure of the EU member states. Consequently, three research questions are set in the paper. First, does fiscal austerity cause any movements vis-à-vis the current account that can be classified as a non-Keynesian adjustment or "expansionary fiscal consolidation? Second, are there differences present with respect to the nature of fiscal austerity (expenditure-based vs tax-based)? Third, are these effects economically significant? Accordingly, a research goal set in this paper is an empirical evaluation of shocks in government purchases and net taxes on the export competitiveness of the eleven new EU member states (Bulgaria, Croatia, the Czech Republic, Estonia, Hungary, Latvia, Lithuania, Poland, Romania, Slovakia and Slovenia). In order to gain a clear policy implication, the paper further divides the countries into subsamples based on their exchange rate regime (the flexible and the fixed exchange rate regime). The working hypothesis of the paper states that fiscal consolidation improves the external competitiveness of national economies, i.e. reducing government deficit results in increasing the level of exports due to compositional shifts in the aggregate demand.

The conducted panel cointegration analysis enables a valid conclusion on the effects of shocks in fiscal policy instruments using impulse response functions and the variance decompositions. The paper adds to the existing literature in the following ways. It uses different measures of fiscal policy as proxies for fiscal austerity (government purchases and net taxes instead of commonly used cyclically adjusted primary balance) and it tests their impact on the level of exports in the eleven new EU member states.

The paper is organized as follows. After the introduction, Section 2 gives a literature review on the link between internal (budget) and external (current account) balance. Section 3 provides an overview of the methodology. Section 4 presents the empirical results and discusses their implications. Section 5 concludes.

\section{The theoretical and empirical literature on the link between budget balance and external competitiveness}

The relationship between budget balance and external competitiveness is analysed from various angles. Studies have included: (i) twin deficit vs twin divergence hypothesis, (ii) the role of wealth, (iii) the role of risk premium and interest rates, (iv) the broader effect of fiscal adjustment on output (non-Keynesian vs Keynesian effect) and (v) the narrow effect of fiscal adjustment on external imbalances (competitiveness).

Ali Abbas et al. [2] present two major causal channels from fiscal policy to the current account: (i) intratemporal trade and (ii) intertemporal responses. The first channel changes the composition of aggregate demand through fiscal policy and the real exchange rate channel thus influences the trade balance. The second channel emphasizes that economic agents are rational and that the economy ends in a Ricardian outcome. An increase in budget deficit induces rational agents to increase their labor supply and decrease their spending, which in the end results in current account improvements.

Theoretical models imply that fiscal austerity should lead to improvements in the current account balance through the exchange rate mechanism (e.g. the Mundell-Fleming model and the open-economy general equilibrium model with overlapping generations, [24]). On the other hand, empirical research suggests that large fiscal adjustments are needed in order to get economically significant effects on the external competitiveness of national economies, i.e. the 
present effects are small and largely insignificant. Increasing them is politically risky and can produce a significant amount of negative social externalities (e.g. the case of the Greek debt crisis). This paper, as well as the existing empirical papers, ignores the political economy effects of political cycles and other electoral and opportunistic determinants as in [1] and [34].

When it comes to empirical studies, confirmation of fiscal austerity, regardless of whether it is expenditure or tax-based, was reported, although with rather small effects, by $[2,6,7,11$, $12,13,14,17]$ and $[22]$.

\section{Methodology}

The relative importance of government purchases and net taxes for the export competitiveness in selected Eurozone countries is analysed using a panel vector autoregression model (PVAR), which takes the following reduced form:

$$
\mathbf{Y}_{\mathbf{i t}}=\Gamma(L) \mathbf{Y}_{\mathbf{i t}}+\mathbf{u}_{\mathbf{i}}+\mathbf{e}_{\mathbf{i t}}, \quad i=1,2, \ldots, N \quad t=1,2, \ldots, T,
$$

where $\mathbf{Y}_{\mathbf{i t}}$ is a vector of endogenous stationary variables, referred to country $i$ in time $t$, and $\Gamma(L)$ is a matrix polynomial in the lag operator, i.e. $\Gamma(L)=\Gamma_{1} L+\Gamma_{2} L^{2}+\Gamma_{3} L^{3}+\ldots+\Gamma_{p} L^{p}$.

Individual heterogeneity of variables is captured by $\mathbf{u}_{\mathbf{i}}$ and $\mathbf{e}_{\mathbf{i t}}$ is an idiosyncratic error. As $\mathbf{Y}_{\mathbf{i t}}$ is a vector of stationary variables, before estimating a PVAR model, we tested stationarity of the variables employed in the analysis performing two panel unit root tests. Because there is a possibility that the data may be cross-sectionally correlated, before testing for unit roots we performed two cross-section dependence tests, i.e. the Breusch-Pagan test [9] and the Pesaran test [28]. The Pesaran cross-section dependence test has the best sample size properties when $T$ exceeds $N$, as is the case in our panel (see [15] for a survey).

If the hypothesis of cross-sectional independence is rejected, we cannot perform the standard panel unit root tests, such as the IPS (Im-Pesaran-Shin [10]), the LLC (Levin-Lin-Chu, [19]) or the Maddala and $\mathrm{Wu}[20]$, which assume independence among cross sections (see for instance [26] and [33]. Instead, the Bai and Ng PCe test [23] and the Pesaran Cross-Sectionally Augmented IPS (CIPS) test [29] were applied. In the Bai and Ng PCe test the individual-common decomposition is performed using one principal component instead of cross-section averages CA as in CIPS [3]. Both tests allow for cross-sectional dependence with the basic assumption that variables can be expressed as a sum of deterministic component and (unobserved) common factors. Thus, in our analysis, we assume that the export or government purchase variables could be desribed as:

$$
\mathbf{x}_{\mathbf{i t}}=\mathbf{d}_{\mathbf{i t}}+\gamma_{\mathbf{i}} \mathbf{F}_{\mathbf{t}}+\varepsilon_{\mathbf{i t}}, \quad i=1,2, \ldots, N \quad t=1,2, \ldots, T,
$$

where $\mathbf{d}_{\mathbf{i t}}$ is a deterministic component, $\mathbf{F}_{\mathbf{t}}$ is a vector of unobserved common factors and $\varepsilon_{\mathbf{i t}}$ is an error term (idiosyncratic component).

The idea of the Pesaran CIPS test is to use the cross-section average $\bar{x}_{t}$ of a variable $\mathbf{x}_{\mathbf{i t}}$ as a proxy for the common factor, which is then included in the model as an additional regressor. On the other hand, in the Bai and Ng PCe test the individual-common decomposition is performed using principal components instead of cross-section averages CA as in the CIPS [3]. The Bai and $\mathrm{Ng}$ test separately applies unit root tests to the common factors as well as the idiosyncratic component of the variable. If only one common factor is estimated (as in our case), an ADF test is conducted. The null hypothesis of a unit root in the idiosyncratic components of all panels is tested via the PMSB test statistics suggested by [4]. Monte Carlo experiments obtained by Bain and $\mathrm{Ng}$ [4] point out that, in the case of a small $N$, PMSB test outperforms all other tests regarding the size properties.

The existence of cointegration between variables was tested by the Pedroni [27] and the Westerlund [33] cointegration tests. Both tests have a common null hypothesis of no cointegration. The alternative hypothesis of the Pedroni test is that the variables are cointegrated in all 
panels. On the other hand, the Westerlund test has two versions of the alternative hypothesis: the variables are cointegrated in some of the panels and the variables are cointegrated in all the panels.

Once the PVAR model has been estimated, the impulse response functions (IRFs) and the variance decompositions (VDCs) were computed. Impulse response functions measure dynamic responses of each variable to one standard deviation shock in other variables. On the other hand, the variance decomposition measures the contribution of each shock to the forecast error variation for all variables in the model. Both information is useful to estimate the impact of shocks in the government purchase and net taxes on export. In calculating IRFs and VDCs, variables have to follow the causal ordering. A variable that is higher in the ordering causes contemporaneous changes in subsequent variables. Variables that are lower in the ordering affect previous variables with a lag.

Since the economic theory or empirical studies do not provide an unambiguous ordering of variables, in our study we selected the following ordering: export, government purchase and net taxes. It seems reasonable to assume that net taxes are contemporaneously affected by the shocks from export and government purchase since the government budget first sets the level of expenditures and only then turns to the revenue side of the budget.

\section{Empirical results}

The effects of shocks in government purchases and net taxes on export competitiveness are analysed for a cross-section of the eleven new EU member states: Bulgaria, the Czech Republic, Estonia, Croatia, Latvia, Lithuania, Hungary, Poland, Romania, Slovenia and Slovakia for the period from 1999 to 2015. Data are provided from the Eurostat base. The results are then compared to the results obtained by splitting the whole sample into two subsamples: countries with the flexible exchange rate regime (the Czech Republic, Hungary, Poland, Romania, Slovenia and Slovakia) and countries with the fixed exchange rate regime (Bulgaria, Estonia, Croatia, Latvia and Lithuania). Slovenia and Slovakia are included in the group of countries with the flexible exchange rate regime due to the fact that Slovenia up to 2007 and Slovakia up to 2009 had been outside the Eurozone and during that time period they had had flexible exchange rate regimes.

We have decided to split the sample since the impact of the exchange rate regime on external competitiveness is unclear. Ali Abbas et al. [2] state that the impact depends on whether the import elasticity of output is higher or lower than the net export elasticity of the exchange rate. Data for exports (volume of exports measured as a percentage of GDP; the variable EXPORT), government purchases (in mil EUR, the variable GP) and net taxes (in mil EUR, the variable NT) are obtained from Eurostat. Taking into consideration the study on Greece conducted by [30], our main interest also focuses on two variables under the influence of fiscal policy.

Government purchases are calculated at the level of general government as a sum of gross fixed capital formation and final consumption expenditure. Net taxes are also calculated at the level of general government as a sum of taxes on production and imports, current taxes on income and wealth, net social contributions and other current transfers (all receivables).

All variables are transformed to natural logarithms (labelled LEXP, LGP and LNT). The results of cross-section dependence tests: the Breusch-Pagan $(\mathrm{LM}=228.562, p$-value $<0.001)$ and the Pesaran $(\mathrm{CD}=9.01, p$-value $<0.001)$ indicate that the null hypothesis of cross-sectional independence is strongly rejected, i.e. that export, government purchases and net taxes exhibit some dynamics common to the countries. Based on the additional analysis, it is assumed that all variables are driven by idiosyncratic elements and a single unobserved common factor. Therefore, unit root testing was performed on the basis of the usual t-statistics of ADF regressions in the common factor and idiosyncratic components, proposed by [3], as well as the pooled PMSB test, proposed by [5]. 
Results of the Pesaran CIPS and the Bai and Ng (Common Factor ADF and PMSB) panel unit root tests, presented in Tables 1 and 2, show that the variable export and the variable net taxes are clearly nonstationary. Based on the additional analysis, it is assumed that all variables are driven by idiosyncratic elements and a single unobserved common factor. Therefore, unit root testing was performed on the basis of the usual t-statistics of ADF regressions in the common factor and idiosyncratic components, respectively. Nevertheless, the results for government purchase variable are not so straight. Namely, based on the results of the Pesaran CIPS test it seems that for some countries the variable is stationary.

\begin{tabular}{|l|cc|cc|}
\hline & \multicolumn{2}{|c|}{ Level } & \multicolumn{2}{c|}{ First difference } \\
\hline variable & constant & constant and trend & constant & constant and trend \\
\hline LEXP & -1.604 & -1.291 & $-2.206^{* *}$ & $-2.261^{* * *}$ \\
LGP & $-2.358^{*}$ & $-3.112^{* *}$ & $-3.762^{* * *}$ & $-3.641^{* * *}$ \\
LNT & -2.088 & $-2.993^{*}$ & $-3.299^{* * *}$ & $-3.217^{* * *}$ \\
\hline
\end{tabular}

Table 1: Pesaran CIPS panel unit root tests; sample period 1999-2015 (statistical significance at $10 \%, 5 \%$ and $1 \%$ are denoted by $\left.{ }^{*},{ }^{* *},{ }^{* * *}\right)$

\begin{tabular}{|l|cc|cc|}
\hline ADF & \multicolumn{2}{|c|}{ Level } & \multicolumn{2}{c|}{ First difference } \\
\hline variable & constant & constant and trend & constant & constant and trend \\
\hline LEXP & -0.938 & $-3.002^{* * *}$ & $-3.855^{* * *}$ & $-3.855^{* * *}$ \\
LGP & $-3.873^{* * *}$ & -3.873 & $-3.603^{* * *}$ & $-3.591^{* * *}$ \\
LNT & $-1.724^{*}$ & -1.373 & $-3.191^{* * *}$ & $-3.184^{* * *}$ \\
\hline PMSB & \multicolumn{3}{|c|}{ Level } & \multicolumn{2}{c|}{ First difference } \\
\hline variable & constant & constant and trend & constant & constant and trend \\
\hline LEXP & -0.606 & -0.157 & $-1.920^{* *}$ & $-1.829^{* * *}$ \\
LGP & -0.381 & 0.220 & $-1.301^{*}$ & -0.938 \\
LNT & 0.520 & 0.810 & $-1.534^{*}$ & $-1.325^{*}$ \\
\hline
\end{tabular}

Table 2: Bai and Ng panel unit root tests; sample period 1999-2015 (statistical significance at $10 \%, 5 \%$ and $1 \%$ are denoted by $\left.{ }^{*},{ }^{* *},{ }^{* * *}\right)$

Nevertheles, we assume that all variables are integrated of order one. As a result, we have to test whether variables are cointegrated. To test whether the potential long-term relationship between variables exists, we perform the Pedroni [27] and the Westerlund tests [33]. The Pedroni test in an alternative hypothesis allows for heterogeneity, i.e. that cointegration for each country exists, but the cointegration relationships differ across countries.

\begin{tabular}{|c|c|c|c|c|}
\hline$H_{0}:$ no cointegration & \multicolumn{4}{|c|}{$H_{1}:$ variables are cointegrated in all panels } \\
\hline $\begin{array}{l}\text { Test } \\
\text { Statistic }\end{array}$ & constant & $\begin{array}{l}\text { Pedroni } \\
\text { constant and trend }\end{array}$ & constant & $\begin{array}{l}\text { Westerlund } \\
\text { constant and trend }\end{array}$ \\
\hline Modified Phillips-Perron & $2.154^{* *}$ & $2.236^{*}$ & & \\
\hline Phillips-Perron & 0.198 & $-2.762^{* *}$ & & \\
\hline Augmentd Dickey-Fuller & $1.826^{* *}$ & -0.801 & & \\
\hline Variance ratio & & & -0.310 & -1.184 \\
\hline Variance ratio $^{a}$ & & & 0.676 & -0.496 \\
\hline
\end{tabular}

Table 3: Panel cointegration tests; sample period 1999-2015 (statistical significance at 10\%, 5\% and $1 \%$ are denoted by ${ }^{*},{ }^{* *},{ }^{* * *}$ and ${ }^{a}$ for $H_{1}$ : variables are cointegrated in some of the panels) 
The results of Pedroni's tests (Table 3) are not unique. On the other hand, both Westerlund's tests, calculated with the Newey and West variance estimator, do not reject the null hypothesis of no cointegration. Thus, an overall conclusion is that the variables in this study are not cointegrated.

The impulse response functions IRF on the Figure 1, show that at the level of the total sample fiscal consolidation affects the level of exports. However, the effect is short-lived (4 years) regardless of the budget side it is carried out at (government purchases or net taxes). The change in government purchases affects exports more (the effect is stronger, approximately three times in the first year) and it soon averages around zero. Results from the variance decompositions (Table 4) confirm this conclusion with shocks in government purchases having the bigger impact than the shocks in net taxes.

These results are in line with Marato and Mulas Granados [21] who emphasize the expenditure based fiscal austerity approach and also with Ali Abbas et al. [2] who find a stronger current account response to fiscal policy changes in the emerging countries. The same effects for increases in government spending are reported in [7, 8, 14], while Beetsma et al. [6] and Tagkalakis [30] find the same effects for government purchases in the case of the ten EU countries and Greece.
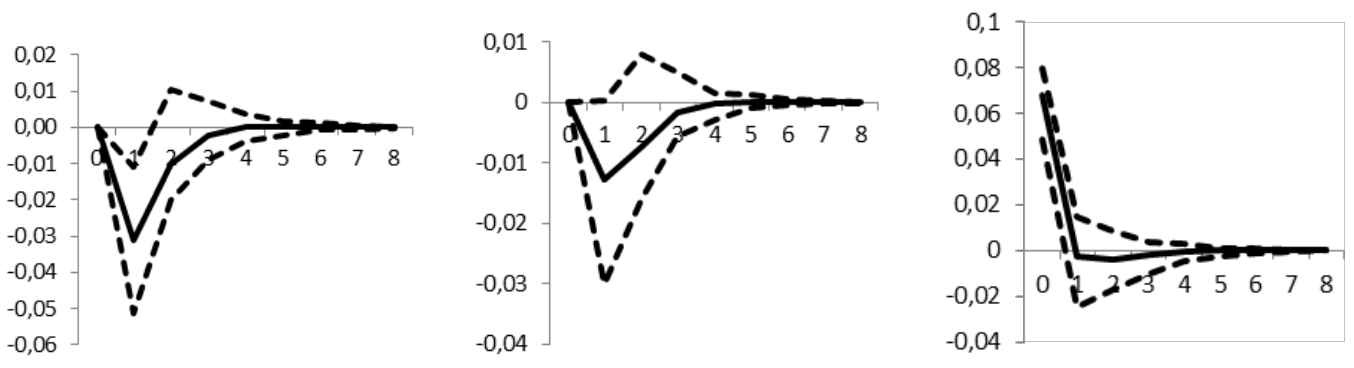

Figure 1: Impulse responses of DLEXP with 95\% confidence intervals, to one standard deviation shock in DLGP (left), DLNT (middle) and DLEXP (right)

The same analysis was then performed on two subsamples: a group of countries with the flexible exchange rate and for the countries with the fixed exchange rate regime. The impulse response functions are presented on the Figures: 2-3 and the variance decompositions for each group are given in Table 4.

\begin{tabular}{|c|ccc|ccc|ccc|}
\hline & \multicolumn{3}{|c|}{ All sample countries } & \multicolumn{3}{c|}{ FLEX exchange rate regime } & \multicolumn{3}{c|}{ FIX exchange rate regime } \\
\hline step & DLEXP & DLGP & DLNT & DLEXP & DLGP & DLNT & DLEXP & DLGP & DLNT \\
\hline 1 & 100.00 & 0.00 & 0.00 & 100.00 & 0.00 & 0.00 & 100.00 & 0.00 & 0.00 \\
2 & 80.30 & 16.84 & 2.86 & 82.59 & 9.74 & 7.67 & 76.86 & 22.98 & 0.16 \\
3 & 78.21 & 18.10 & 3.69 & 80.28 & 12.18 & 7.53 & 72.76 & 23.49 & 3.75 \\
4 & 78.14 & 18.14 & 3.72 & 80.27 & 12.20 & 7.53 & 72.44 & 23.59 & 3.96 \\
5 & 78.14 & 18.14 & 3.72 & 80.27 & 12.20 & 7.53 & 72.42 & 23.59 & 3.99 \\
6 & 78.14 & 18.14 & 3.72 & 80.26 & 12.20 & 7.53 & 72.42 & 23.59 & 3.99 \\
\hline
\end{tabular}

Table 4: Variance decomposition (ordering: DLEXP, DLGP, DLNT) 

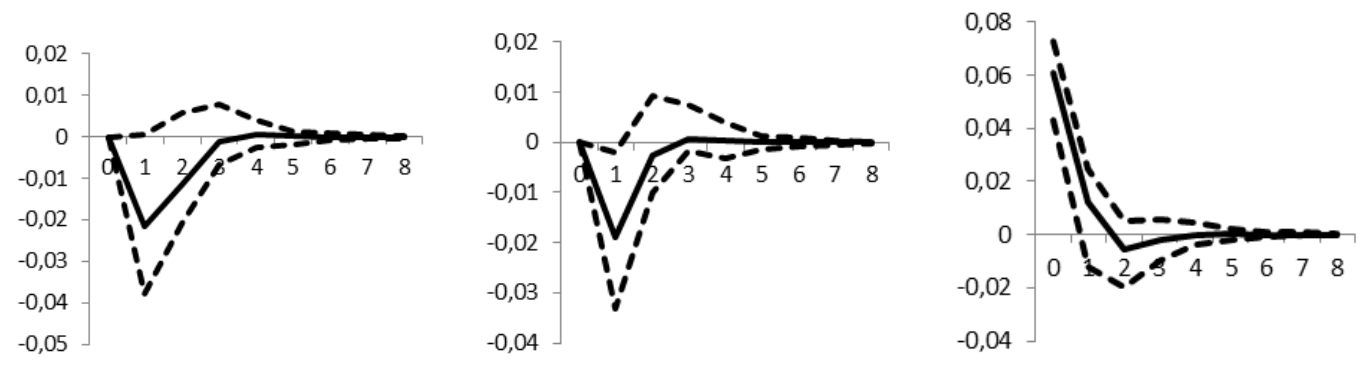

Figure 2: Impulse responses of DLEXPORT with 95\% confidence intervals, to one standard deviation shock in DLGP (left), DLNT (middle) and DLEXPORT (right) for countries with flexible exchange rate regime

At the subsample level of six countries with a flexible exchange rate mechanism, we have proved that fiscal consolidation affects the level of export. We have also confirmed that the duration effect found in the total sample does not change once we focus on these six countries. Namely, the effect vanished after 3-4 years. The IRF (Figure 2) shows that the change in net taxes is the only important instrument of fiscal policy when it comes to exports, although shorter (it vanishes after 3 years). And finally, the effect of net taxes is stronger than the one obtained at the total sample level. Results from the variance decompositions (Table 4) confirm this conclusion. These results are channelled through the nominal exchange rate depreciation that took place in Hungary, Romania and Slovenia during the observed time period. Tsibouris et al. [31] based their conclusion that the tax-based fiscal consolidation works only at the initially low level of tax revenues in GDP, but we claim that it is the exchange rate mechanisms that is important.
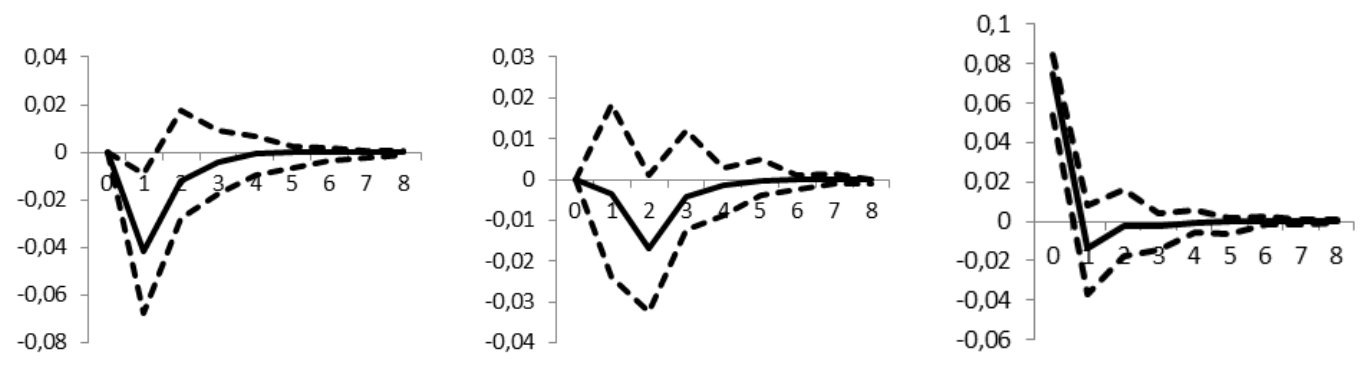

Figure 3: Impulse responses of DLEXPORT with 95\% confidence intervals, to one standard deviation shock in DLGP (left), DLNT (middle) and DLEXPORT (right) for countries with fixed exchange rate regime

Our last estimation concerns the subsample of five countries that have a fixed exchange rate mechanism. The results are in line with the ones obtained at the total sample level. Namely, our working hypothesis that the fiscal consolidation affects the level of exports is validated also at this subsample. The duration effect is the same (4 years), but it is stronger in the case of government purchases, the change of which is the only important instrument of fiscal policy when it comes to exports. Again, the results confirm the conclusion by $[6,8,21,30]$.

With respect to the theory, we can conclude that the results are in opposition to the MundellFleming model since we verify that under a fixed exchange rate regime an expansionary fiscal shock crowds out exports. 


\section{Conclusion}

This paper has analysed the link between fiscal policy (shocks in government purchases and net taxes) and the external competitiveness. The working hypothesis has been confirmed. In the sample of the eleven new EU member states in the time period 1999-2015, the fiscal consolidation actually improves external competitiveness by increasing the level of exports of the national economies. The dominant channel is expenditure-based. With respect to the research questions, we can conclude that the paper has answered all of them.

The paper's contribution to the existing literature is fourfold. First, it has empirically confirmed that the effects of the fiscal austerity on the external competitiveness are rather short-lived (approximately 4 years). Second, the results point to a clear policy implication visà-vis different exchange rate regimes (expenditure-based fiscal austerity is preferred in the total sample and in the subsample of countries that have the fixed exchange rate regime). Shocks in net taxes influence the level of export only in the countries that have flexible exchange rate regimes, but the predominant effects are still tied to the shocks in government purchases even in this subsample. Third, it uses shocks in government purchases and net taxes instead of cyclically adjusted primary balance as a proxy for fiscal policy, which yielded inconclusive results in the existing empirical literature. Fourth, it empirically tested the relationship between shocks in government purchases and net taxes on one side and the external competitiveness on a panel of the eleven new EU member states.

One question does remain with respect to both duration and the size of the estimated effects: Does statistical significance imply economic importance? The results are statistically valid, but small effects that vanish after 4 years are not to be neglected. They point to a short time span which is clearly the main limitation of the study since it influenced the econometric model itself. Thus, future research should put special focus on the recession period and take into consideration zero lower bound periods and ECB unorthodox policy measures. A further division between recessions and expansions is preferred with respect to the policy implications of the obtained results. Alternative methodologies should also be taken into consideration and preferably data on quarterly and monthly intervals should be used.

\section{Acknowledgements}

This work has been fully supported by the Croatian Science Foundation under the project IP-2014-09-5476.

\section{References}

[1] Alesina, A. and Perotti, R. (1994). The Political Economy of Budget Deficits. NBER Working Paper Series, Cambridge, 4637, 1-56. doi: 10.3386/w4637

[2] Ali-Abbas, S. M., Bouhca-Hagbe, J., Fatas, A., Mauro P. and Velloso, R. C. (2010). Fiscal Policy and the Current Account. IMF Working Papers, 121, 1-30. doi: /10.5089/9781455200801.001

[3] Bai, J. and Ng, S. (2004). A PANIC Attack on Unit Roots and Cointegration. Econometrica, 72(4), 1127-1177. doi: 10.1111/j.1468-0262.2004.00528.x

[4] Bai, J. and Ng, S. (2010). Panel unit root tests with cross-section dependence: a further investigation. Econometric Theory, 26(4), 1088-1114. doi: 10.1017/s0266466609990478

[5] Belke, A. and Potrafke, N. (2012). Does government ideology matter in monetary policy? A panel data analysis for OECD countries. Journal of International Money and Finance, 31(5), 1126-1139. doi: 10.1016/j.jimonfin.2011.12.014

[6] Beetsma, R. and Giuliodori M. (2011). The effects of government purchases shocks: review and estimates for the EU. The Economic Journal, 121(550), 4-32. doi: 10.1111/j.1468-0297.2010.02413.x

[7] Beetsma, R., Giuliodori, M. and Klaassen, F. (2008). The Effects of Public Spending Shocks on Trade Balances and Budget Deficits in the European Union. Journal of the European Economic Association, 6(2-3), 414-423. doi: 10.1162/jeea.2008.6.2-3.414 
[8] Bluedorn, J. and Leigh, D. (2011). Revisiting the Twin Deficits Hypothesis: The Effect of Fiscal Consolidation on the Current Account. IMF Economic Review, 59(4), 582-602. doi: 10.1057/imfer.2011.21

[9] Breusch, T. S. and Pagan, A. R. (1980). The Lagrange Multiplier Test and its Applications to Model Specification in Econometrics. Review of Economic Studies, 47(1), 239-253. doi: $10.2307 / 2297111$

[10] Bun, M. J. G. and Kiviet, J. F. (2006). The effects of dynamic feedbacks on LS and MM estimator accuracy in panel data models. Journal of Econometrics, 132(2), 409-444. doi: 10.1016/j.jeconom.2005.02.006

[11] Bussière, M., Fratzscher, M. and Müller, G. J. (2010). Productivity shocks, budget deficits and the current account, Journal of International Money and Finance, 29(8), 1562-1579. doi: 10.1016/j.jimonfin.2010.05.012

[12] Chinn, M. D. and Prasad, E. S. (2003). Medium-term determinants of current acounts in industrial and developing countries: an empirical exploration. Journal of International Economics, 59(1), 47-76. doi: 10.1016/s0022-1996(02)00089-2

[13] Chinn, M. D. and Ito, H. (2007). Current account balances, financial development and institutions: Assaying the world "saving glut". Journal of International Money and Finance, 26(4), 546-569. doi: 10.1016/j.jimonfin.2007.03.006

[14] Corsetti G., Meier A. and Müller G. J. (2012). What determines government spending multipliers? IMF Working Papers, 12(150), 1-46. doi: 10.5089/9781475504217.001

[15] De Hoyos, R. E. and Sarafidis, V. (2006). Testing for Cross-Sectional Dependence in Panel-Data Models. The Stata Journal: Promoting communications on statistics and Stata, 6(4), 482-496. doi: 10.1177/1536867x0600600403

[16] Ehrmann, M. and Fratzscher, M. (2011). Politics and Monetary Policy. The Review of Economics and Statistics, 93(3), 941-960. doi: 10.1162/REST_a_00113

[17] Gruber, J. W. and Kamin, S. B. (2007). Explaining the Global Pattern of Current Account Imbalances. Journal of International Money and Finance, 26(4), 500-522. doi: 10.1016/j.jimonfin.2007.03.003

[18] Klomp, J. and de Haan, J. (2010). Inflation and Central Bank Independence: A Meta-regression Analysis. Journal of Economic Surveys, 24(4), 593-621. doi: 10.1111/j.1467-6419.2009.00597.x

[19] Levin, A., Lin, C. F. and James Chu, C. S. (2002). Unit root tests in panel data: asymptotic and finite-sample properties. Journal of Econometrics, 108(1), 1-24. doi: 10.1016/s03044076(01)00098-7

[20] Maddala, G. S. and Wu, S. (1999). A Comparative Study of Unit Root Tests with Panel Data and a New Simple Test. Oxford Bulletin of Economics and Statistics, 61(1), 631-652. doi: 10.1111/14680084.0610s1631

[21] Marato, R. and Mulas Grandos, C. (2007). What Makes Fiscal Policy Sustainable? A Survival Analysis of Fiscal Consolidations in Europe (1960-2004). Public Choice, 134(3-4), 24-46. doi: $10.1007 / \mathrm{s} 11127-007-9211-8$

[22] Mohammadi, H. (2004). Budget deficits and the current account balance: New evidence from panel data. Journal of Economics and Finance, 28(1), 39-45. doi: 10.1007/bf02761453

[23] Newey, W. K. and West, K. D. (1994). Automatic lag selection in covariance matrix estimation. , 61(4), 631-653. doi: 10.2307/2297912

[24] Obstfeld, M. and Rogoff, K. (1996). Foundations of International Macroeconomics. Cambridge: MIT Press.

[25] Örsal, K. D. D. (2008). Comparison of Panel Cointegration Tests. Economics Bulletin, 3(6), 1-20. https://ideas.repec.org/a/ebl/ecbull/eb-07c10009.html

[26] Pedroni, P. (1999). Critical Values for Cointegration Tests in Heterogeneous Panels with Multiple Regressors. Oxford Bulletin of Economics and Statistics, 61(1), 653-670. doi: 10.1111/14680084.0610s1653

[27] Pedroni, P. (2004). Panel cointegration: asymptotic and finite sample properties of pooled time series tests with an application to the PPP hypothesis. Econometric Theory, 20(3), 597-625. doi: $/ 10.1017 / \mathrm{s} 0266466604203073$

[28] Pesaran, M. H. (2004). General diagnostic test for cross section dependence in panels. , University of Cambridge, 435. https://ideas.repec.org/p/cam/camdae/0435.html 
[29] Pesaran, M. H. (2007). A simple panel unit root test in the presence of cross-section dependence. Journal of Applied Econometrics, 22(2), 265-312. doi: 10.1002/jae.951

[30] Tagkalakis, A. O. (2015). Fiscal Policy, Net Exports, and the Sectoral Composition of output in Greece. International Economics and Economic Policy, 12(4), 521-539. doi: 10.1007/s10368-0140285-8

[31] Tsibouris, G. C., Horton, M. A., Flanagan, M. J. and Maliszewski, W. S. (2006). Experience with Large Fiscal Adjustments. IMF Occasional Papers, 1-51. doi: 10.5089/9781589064584.084

[32] Wagner, M. and Hlouskova, J. (2009). The Performance of Panel Cointegration Methods: Results from a Large Scale Simulation Study. Econometric Reviews, 29(2), 182-223. doi: $10.1080 / 07474930903382182$

[33] Westerlund, J. (2005). New Simple Tests for Panel Cointegration. Econometric Reviews, 24(3), 297-316. doi: 10.1080/07474930500243019

[34] Wren-Lewis, S. (2017). A general theory of austerity, 17-36. In Heffernan, E., McHale, J. and Moore-Cherry, N. (Eds): Debating Austerity in Ireland: Crisis, Experience and Recovery, Royal Irish Academy. doi: 10.2307/j.ctt1x76dck.8 